\title{
Revolutionary insurgencies, paradigmatic cases
}

Book or Report Section

Accepted Version

Kumaraswami, P. (2015) Revolutionary insurgencies, paradigmatic cases. In: Szurmuk, M. and Rodríguez, I. (eds.) The Cambridge History of Latin American Women's Literature. Cambridge University Press, New York, pp. 228-242. Available at http://centaur.reading.ac.uk/38315/

It is advisable to refer to the publisher's version if you intend to cite from the work. See Guidance on citing.

Publisher: Cambridge University Press

All outputs in CentAUR are protected by Intellectual Property Rights law, including copyright law. Copyright and IPR is retained by the creators or other copyright holders. Terms and conditions for use of this material are defined in the End User Agreement. 


\section{CentAUR}

Central Archive at the University of Reading

Reading's research outputs online 
19. Revolutionary Insurgencies, Paradigmatic Cases

Par Kumaraswami, University of Manchester

\section{Abstract}

This essay will examine and compare the production of women's writing during and after the Nicaraguan and Cuban Revolutions, a corpus that includes novels, poetry, and testimonies, but also features considerable generic hybridity. Since both revolutions are separated by some twenty years, each must be understood in the context of the specific ideological conditions that framed women's participation in culture and revolution, and must also be considered in light of evolving gender discourses, both national and international. As such, these texts respond to both local and transnational paradigms of feminine subjectivity, and highlight the particular problems that arise from women's insertion into the revolution and its representation in literature. These writers also have to negotiate the evolving context of revolution itself, with its moments of euphoria and disenchantment - and it is here that the greatest contrasts can be found between the two revolutionary instances and their political features: whilst Cuba's revolutionary process has somehow survived economic crisis and created a level of political stability and continuity (not without its own problems), the Nicaraguan case is characterised by ruptures and resentments which are clearly reflected in the work of writers before, during, and after the Sandinista revolution, and which continue to the present day. This chapter will address the work of the most prominent woman writer of the Nicaraguan revolution, Gioconda Belli, whose main work reflects her involvement in the Sandinista struggle; ex-commander Mónica Baltodano has recently compiled a four volume piece with testimonials of men and women who participated in the organization and actions led by the Frente Sandinista de Liberación Nacional, and Violeta Barrios de Chamorro, former president of Nicaragua, who has recently co-authored an autobiography. There are other women poets to consider, especially under the auspices of the Asociación de Mujeres Nicaraguenses Luisa Amanda Espinoza, such as Vidaluz Meneses, Michele Najlis and Daisy Zamora. The testimonios compiled by Margaret Randall are also important pieces to consider for both Nicaragua and Cuba. The most important voices of the Cuban revolution still resident on the island are poet Nancy Morejón and writers Mirta Yáñez and Aida Bahr, with younger writers such as Adelaida Fernández de Juan and Marilyn Bobes representing a more recent generation. 
This chapter compares the development of women's writing in two overlapping but distinct revolutionary contexts: the Cuban Revolution from 1959 to the present, and the Nicaraguan Revolution of 1979-1990, privileging work produced within (or after, in the case of Nicaragua) the process of political and social revolution. This is, of course, a vast and diverse corpus of texts that includes novels, poetry, and testimonial texts produced not only by established writers but also by groups that emerged from socio-cultural policy initiatives established by each country's revolutionary processes of cultural massification. As a result, these literary canons feature a considerable generic hybridity of texts that serve as snapshots in a process of social change.

Each revolutionary context had to contend with the troubled relationship between left-wing Latin American revolutionary projects and feminist ideas, an assumption which revolved around the assumption that any privileging of gender would a) undermine the class-based project of socialist revolution and b) disarticulate the process of nation-building, equality and social justice by focusing excessively on the needs of one particular social category. However, other problematics emerge: any attempt to account for women's literary production in these fragile contexts must include a consideration of other forces that shape and mediate both the construction of subjectivity and the production of literature, especially in contexts that are literarily, if not always politically, peripheral: from the 1980s onwards, several new forces came into play to shape the production and consumption of many of these texts, including the impact of international and transnational feminist currents and of foreign publishers and readerships in translation.

Thus, the paradigmatic nature of many of these texts, often perceived as the inevitable consequence of socialist or communist political systems - in Cold War mode - that demanded or coerced conformity of self and self-expression, needs some nuancing. In an environment of postcolonial and postdictatorship nation-building, however, culture especially by being massified and democratized through cultural participation in statesponsored policy initiatives and cultural institutions - became not only the glue that bound social groups within a broad concept of nation, but also the space that enabled the subjectivity and self-expression of previously marginalized citizens to develop and emerge, always within that concept of nation, and often with a largely exteriorized subjectitivy on display. In this sense, there are important parallelisms of paradigms of self and self-representation between the two processes. 
Of course, any assessment of a revolutionary process is necessarily influenced by the political and ideological background - and often utopian desires - of the researcher, and the cases of Cuba and Nicaragua are no exception. The Cuban Revolution is most frequently seen outside Cuba as a failed socialist or communist political experiment, often through applying an equally-simplified template of Sovietisation: as a result, post-1959 Cuba is erroneously understood through a reduction of its complexities to the assumption that the infamous quinquenio gris of 1971-76, and the parameters it imposed, in fact summarises the entire breadth and depth of the revolutionary literary environment (Kumaraswami and Kapcia). In the case of Nicaragua, however, and especially in early comparative work, a different assumption rightly emerges from the foreign scholarship: that Nicaragua's short-lived revolution, often described as a revolution of poets, was inherently pluralistic, less markedly Marxist or socialist in its ideological direction, less isolated and inward-looking and more open to incorporating different interest groups and exogenous currents (Craven).

Nevertheless, it is important also to note the considerable parallels in these two processes and, in particular, to recognize that both have been largely motivated by a project of nationbuilding, national sovereignty, wealth redistribution and social justice (Dore and Weeks; Kapcia) rather than by a strictly communist or socialist agenda. Indeed, in the areas of cultural policy and practice, Nicaragua chose to borrow and modify many of the models that the Cuban revolutionary experiment had developed in the 1960s and 1970s: the immediate implementation of a nationwide literacy campaign, with Cuban advisors who had "cut their teeth" in Cuba's 1961 Campaña de Alfabetización being invited to help design policy and training for the Nicaraguan Cruzada Nacional de Alfabetización of 1980; the founding of a nationwide infrastructure of cultural centres for mass participation (in Cuba, the Casas de Cultura, in Nicaragua, the Centros Populares de Cultura); a similarly broad-reaching system of writing workshops (in Cuba, via the system of talleres literarios, formed in the early 1970s, in Nicaragua, via the Centros Populares de Cultura and the Talleres de Poesía movement launched by Minister of Culture Ernesto Cardenal in 1980); and, crucially, a national film institute to reorient the direction of production and consumption of a vitally influential mass cultural form (ICAIC in Cuba just three months after the Revolution came to power, and INCINE in Nicaragua, founded soon after the Sandinista victory in 1979, once again, with advice from Cuban specialists). 
Other factors should be considered: namely, that in the Cuban case it was to some extent precisely the 'siege mentality' (Kapcia 2000) and insistence on sovereignty and institutionalism (coupled of course with a 'special' relationship with the US which facilitated the exodus of individuals and social groups who disagreed with the direction that the Revolution was taking after 1961) that created, largely through the disappearance of the middle classes, the possibility of sustaining the revolutionary project (with cultural life deeply imbricated in the socio-political process) and ultimately ensuring the survival of the Cuban Revolution (Kumaraswami and Kapcia). The case of Sandinista Nicaragua might, therefore, be considered ultimately, and with the benefit of hindsight, as a bourgeois revolution which attempted to provide a cohesive focus and ideology for Nicaraguan society, but which was eventually hindered by unresolved class conflict which ultimately created insurmountable contradictions in the run-up to the 1990 elections in which the Sandinista government was ousted and Violeta Barrios de Chamorro was elected.

Understanding the complexity of each context for women also allows us to explore how women's writing in each case responded to local, national and transnational paradigms of feminine subjectivity, and highlights the particular problems that arise from women's insertion into 'the revolution' and its representation in literature. Several parallel strands emerge here: importantly, each nation's incipient revolutionary movements incorporated key female figures as incarnations of the notion of 'mother of the nation': in the case of the late $19^{\text {th }}$ century movement in Cuba, Mariana Grajales Coello, the mother of Antonio Maceo, was iconised as 'la madre de la patria' and is still part of the small pantheon of symbolic female figures that connect independence to insurrection and revolution over one hundred years. In the case of Nicaragua, these incons found their expression principally after 1979, an important example being Luisa Amanda Espinoza, one of the first guerrilllera victims of the insurrection. In both processes, the insertion of a feminine presence in public life was initially legitimized by the participation of women in the process of insurrection against dictatorship: this participation ranged from clandestine urban activity (Haydée Santamaría, Vilma Espín, Celia Sánchez and others in Cuba; Claribel Alegría; Belli, Najlis and Zamora in Nicaragua) to active service as combatientes in the guerrilla forces (Celia Sánchez and Vilma Espín, amongst others, in Cuba; Mónica Baltodano, amongst others, in Nicaragua). Once the revolutionary leadership achieved power, many of these key female figures of the insurrection were given positions of political, social and cultural leadership: Santamaría was named Director of Havana's Casa de las Américas; Belli became a prominent information 
officer in Managua. Other trusted female figures were rewarded for their efforts during the insurrection by being given the leadership of the new mass organizations for women: the Federación de Mujeres Cubanas, founded in 1960 and headed by Vilma Espín; first conceived in 1977 as AMPRONAC (Asociación de Mujeres ante la Problemática Nacional), AMNLAE (Asociación de Mujeres Nicaragüenses Amanda Luisa Espinoza) was founded in 1979 , under group leadership. In this sense, the credibility of women as a socio-cultural group in each revolutionary context was established principally by the recognition of their revolutionary credentials and level of compromiso as evidenced by insurrectionary action, and any subsequent participation in the world of letters, at least initially, often mirrored that new socio-political profile.

Once each revolution came to power, key legislation and policy was developed to address the social conventions that had hitherto restricted women's lives in each context: universal access to education, the Family Code, universal access to contraception and abortion, a state infrastructure of childcare facilties, the promotion of breastfeeding, the elimination in Nicaragua of the 'family wage', the elimination of widescale prostitution, and the loosening of bureaucracy and laws for divorce and separation, reflected the new role of women as actors in the public sphere, and as workers. However, other radical social changes were achieved almost accidentally: one of the most influential phenomena in occasioning rapid social change in Cuba was the Literacy Campaign, which mobilized a predominantly female, urban and middle-class sector of young women (some as young as 13) to travel to underdeveloped rural areas of the island as literacy teachers. The Cuban cultural and political leadership soon recognized the effectiveness of processes of consciousness-building or concientización through action, and the experience was central to the self-construction of many young women. By the time of the Sandinista Revolution, that lesson had been learnt.

Despite huge advances in the public sphere, however, little real change was effected in terms of women's continued role in the domestic sphere, and, of course, the roles of men changed little. In addition, assessment of sociocultural change progress was predominantly measured in quantitative terms, through statistical date which accounted for sex but not for gender (Riess). Despite sustained commitment to the socialization, massification and democratization of literature through the many cultural initiatives noted above, gender inequality was particularly noticeable in the literary environment: over two decades after the Cuban revolution had come to power, Cuban feminist scholars such as Luisa Campuzano felt 
it necessary to deliver a powerful critique of gender inequality in literary production. Her 1984 and 1988 exhortations to incorporate women writers into the Cuban literary arena (Campuzano Quirón) paved the way for a re-examination of gender within revolutionary culture. Campuzano's paper, presented to the 1984 Primer Forum de Narrativa Cubana, and published in augmented form some four years later, contrasted the idealised and optimistic portrayal of Cuban letters in the 1980s with stark statistics illustrating women's lack of incorporation into cultural production. Campuzano concluded by highlighting the centrality of women to the literary process at all its stages: 'Porque si bien es cierto que la mujer apenas escribe o protagoniza cuentos y novelas, sin embargo es ella quien, tanto en éste como en otros campos de la vida artística y literaria, más contribuye a su concreción, a su circulación y a su consumo' (Campuzano Quirón 103). Campuzano's work incited a new generation of women scholars - themselves informed and encouraged by feminist currents in Europe and the US - to address the gender question in qualitative terms, and to draw attention to the pressures on women that had resulted from the social policy of the early years: the doble or triple jornada that was incarnated in the iconic image often published in the mainstream national press in both Cuba and Nicaragua of the female revolutionary, Kalashnikov slung over the shoulder, glamorous in verde olivo, and with babe in arms (Smith 3; Davies 120).

Thus, in society at large and under the auspices of the mass organizations for women, a distinction began to emerge between feminist and feminine approaches, a debate that was played out (and that ultimately led to a schism in the Nicaraguan case) between those women actors who were content to 'serve' the Revolution by accepting and being complicit with the (patriarchal) power structures, and those who were disillusioned that the apparent radicalism of the revolutionary project had not extended to gendered questions of power. Indeed, in the case of the Sandinista movement, the eventual collapse of the FSLN and the election of Violeta Barrios de Chamorro has been widely recognized as being the result of several important sectors of the population feeling that not only had their agendas been used strategically by the FSLN in order to consolidate its power base, but also that the FSLN's strategic vision had neutralized, and to some extent reinforced, the structural inequalities which it had promised to dismantle. Maxine Moylneux's analysis of the women's movement in Nicaragua, for example, centers on the notion that the FSLN's practical objectives to mobilize large sectors of the population, including women, denied those sectors true emancipation through refusing to engage with the strategic interest of those groups (Molyneux). 
In all events, in both contexts, the tendency of the revolutionary government lent heavily towards seeing gender as a product of class-based inequalities, a bourgeois capitalist past and economic dependence. As Tomás Borge, Nicaraguan Minister of the Interior and one of the three founding members of the FSLN, expressed it: 'The woman question is nothing more than an aspect of social reality in its totality. The definitive answer to the liberation of women can emerge only with the total resolution of the class contradictions, of the social diseases that originate in a society like ours - politically liberated but with the rope of economic dependence around our neck' (Borge 10). The solution, then, lay in changing the economic system rather than changing socio-cultural practices and paradigms.

\section{Changing the rules of the game: creating a new literary culture}

As mentioned, despite significant advances in the public sphere, women's incorporation into the literary establishment was cautious and, initially at least, was framed in terms of political, rather than cultural, credentials. At the same time, however, policies of cultural massification had created new spaces and new models of writing that had the potential to be radical and farreaching: indeed, in Fidel Castro's 1961 'Palabras a los intelectuales', his closing statement signaled a new conceptualization of literature that was based on life experience and relevance to the collective (especially hitherto marginalized social sectors), rather than the traditional parameters of literary worth - aesthetic experimentation, inaccessibility (hermeticism), disassociation from social life (and especially political life) - these traditional criteria now bring dismissed as bourgeois, conservative, elitist, a relic of colonialism and neo-colonialism. His speech ended by drawing attention to a newly-literate female ex-slave, then aged 106, who had the potential to become a writer : 'Creo que puede escribir una cosa tan interesante que ninguno de nosotros la podemos escribir. Y es posible que en un año se alfabetice y además escriba un libro a los 106 años — ¡ esas son las cosas de las revoluciones! — y se vuelva escritora y tengamos que traerla aquí a la próxima reunión (RISAS y APLAUSOS)' (Castro np).

In terms of cultural policy designed to massify participation, many parallels can be drawn between both contexts: the general objective was to dissolve the boundaries between elite and popular culture, but also to recalibrate the functions of literary production in the new cultural landscape. The initial periods of both revolutionary processes were not without their tensions 
and acrimonious debates, many of which revolved around how to define revolutionary literature in a context in which the majority of the population was now literate, if only in functional terms. The relationship between politics and literature was especially contested in the early years of the Cuban Revolution, with a deeply-felt suspicion on the part of some sectors of the political leadership that the contribution of artists and intellectuals was inherently inferior to the more 'practical' political or military commitment of other Cubans, and that artists and intellectuals were also necessarily 'contaminated' by liberal or foreign bourgeois ideas. However, despite moments of crisis, through a process of institutionalisation of culture and through recourse to a historical tradition of associating literature with individual and collective emancipation (building on José Martí's concept 'ser culto es ser libre'), writers gained prestige by attracting mass reception, whilst the general public gained symbolic capital both through accessing the literary canon and through participating actively in talleres, literary competitions in the workplace, and other spaces for production and reception.

As noted, Nicaragua broadly followed the patterns of cultural policy established some twenty years earlier in Cuba. With the prominent novelist Sergio Ramírez as Vice-President of the Sandinista government, liberation theologists Ernesto and Fernando Cardenal as Ministers of Culture and Education for most of the Sandinista's term in office, the development of Ernesto Cardenal's Solentiname cultural community, and a nationwide network for writing and publishing, many mechanisms and actors were put in place in order to institutionalise cultural participation. Just as some might argue that Cuba's cultural policies privileged the written word and neglected or 'folklorised' Afro-Cuban and rural cultural practices, it could be asserted that the Sandinista objective excluded the Miskito population, and followed largely urban, middle classes aspirations for culture. In both cases, then, the issue at stake was how nation-building through culture could address the social heterogeneity of each population, and in both cases, that social diversity was often subsumed under class conflict and thus sidelined.

\section{Writing the Revolution: The testimonial mode}

Perhaps the most noticeable means of expression in both post-revolutionary contexts was the testimonial mode, a hybrid category which allowed literature to fulfil several important functions: to record history, to 'subjectivise' hitherto excluded voices, to act as a didactic or 
even motivational tool, and to collectivise the experience of each revolutionary nation by 'putting a face' on ideology (Fagen 1969; Medin 1990). As Carolyn Steedman stated in her study of writing, autobiography and history, 'Material circumstances produce prose, audiences are configured on economic bases which determine the relationship between readers and writers, and between the words on the page and what actually gets read' (Steedman xi). In the context of radical socio-political change which one the one hand demanded participation but on the other was wary of women's incursion into new areas of the public sphere, the life experience of emerging women writers, which Steedman characterises as 'the massive authority this appeal to the evidence will give her as a story-teller' (Steedman 47) was a crucial socio-political, rather than economic, mechanism in both Cuba and Nicaragua for reinforcing the credibility and authority of the female revolutionary writing subject, but also for making the Revolution meaningful at a personal level.

How, then, did women's presence in each revolution's world of letters reflect these changing contexts? The initial space for expression in both contexts, whether in prose or poetry, came via the testimonial mode, which served several functions: it allowed women who lacked the symbolic and social capitals associated with the world of letters - an existing oeuvre, literary training, social and cultural networks - both to 'jump-start' their entrance into print as well as to neutralize the threat posed by their potentially transgressive incursion into the literary environment by representing their experiences of the revolution via testimonial texts, thus underlining their involvement in the socio-political process.

Whilst self-writing is often perceived as being less artistically demanding, more 'natural' for women whose writing practices have been expected to conform to the characterization of women's writing as urge, confession, intimacy and interiority (such as the diary and epistolary genres), the outward-looking nature, or exteriority, of these initial texts was transgressive in its own way. Whilst there is little in the way of self-reflexion regarding writing on the part of the first generation of Cuban women writers after 1959, in the Nicaraguan case, memoirs such as those of Belli (Belli 2001), albeit written with the retrospective filters that tend towards producing coherent narratives of self and life, give us some biographical information regarding the difficulties of entering the literary establishment for women. Nevertheless, despite a common testimonial tendency, significant differences can be established between the respective first waves of 'post-revolutionary' women's writing in Cuba and Nicaragua. 
In Cuba, a tradition of female writers pre-1959 (Dulce María Loynaz, Carilda Oliver Labra, Lydia Cabrera) was soon neglected or disappeared from the island's literary canon as new mechanisms and criteria for publishing emerged: whilst this was also certainly true for male writers before 1959, in the case of women, their limited participation in pre-revolutionary literary production meant that emigration left an almost complete vacío or void. This allowed emerging writers both to 'start afresh' but also obliged them to insert themselves in the new literary landscape. However, the first two decades of the Revolution also genuinely changed the rules of the game and enabled new conceptions of self and writing to be established. The rapid legitimisation of the testimonial mode (made a prize category in Casa de Las Américas in the early 1970s, although clearly privileging testimonial texts recounting the military feats of the insurrection, the victory and, soon after, the Bay of Pigs) meant that young women who had participated in various initiatives of voluntary work, could represent their achievements and observations in textual form, often with a high level of formal hybridity, and straddling the divide between fact and fiction: from Daura Olema García's fictionalised account of a young urban woman's participation in the first post-1959 literacy brigades, Maestra voluntaria (Olema García), Nancy Morejón and Carmen Gonce's ethno-historical study, but also poetic reflection, of the eastern Cuban town of Nicaro, Lengua de pájaro: comentarios reales (Morejón and Gonce), Mirta Yáñez’s provocative collection of short stories Todos los negros tomamos café, reflecting the daily and often domestic experience of revolutionary change (Yáñez), and Mercedes Santos Moray’s La piedra de cobre, a compilation of shorter articles narrating the conflicts and successes of voluntary work both undertaken and observed by the author in the 1960s (Santos Moray), these were texts that used the lived experiences of their authors as a springboard to depict a collective process, often underlining the tensions and contradictions that the eruption of the revolutionary process in a highly machista society implied for women, but rarely articulating these gendered concerns in a strident or even explicit manner. These hybrid texts were frequently the result of compiling shorter newspaper articles or discrete short stories and essays, often to submit a fuller manuscript to state-sponsored literary prize categories and, as result, rarely have the coherence - of subjectivity and narrative arc - that is one of the hallmarks of traditional self-writing. Perhaps more importantly for this analysis, they display a remarkable level of consensus between writing self and context: in other words, the process of living and recording the early euphoric period of the revolution, of recording history-in-the-making, is articulated in such a way that the individual and social selves merge seamlessly, in spite of 
differences of race and class, in service of the greater project: the Revolution. Whilst some scholars (Serra) have argued that these texts thus demonstrate how the political hegemony morally and ideologically coerced the Cuban population into conformity, specifically in order to conform to the blueprint of the hombre nuevo proposed by Ernesto 'Che' Guevara in 1965, other commentators (Campuzano Cuba 1961; Kumaraswami Pensamos que somos historia) argue that these texts offered articulations of self that were neither coerced nor freely given, but that rather created a psychosocial mechanism for women to a) integrate themselves as individuals and as a social category in the revolutionary process, b) publicise and legitimise their participation in public life, c) rehearse their involvement in the revolutionary process and d) construct their evolving identity via the act of narration. In this sense, the testimonial mode offered the opportunity for paradigms of gendered political insurgency.

In the 1980s, and particularly as Cuban cultural life emerged slowly from the corrosive effects of the quinquenio gris, new generations of writers illustrated the results of the socialization of the literary environment (Riess 120). To some extent, this phenomenon reflected the quantitative achievements of the revolution in educational terms, as well as what is considered to be the 'golden age' for publishing ushered in by the creation of the Ministry of Culture in 1976. However, the same period, perhaps precisely because many more pressing concerns had been alleviated, also indicated a more oppositional and militant response to the gender problem amongst Cuban women writers and intellectuals, undoubtedly following the tendencies of international feminist currents. Campuzano's essays therefore sounded an early warning that gender politics could no longer be usefully subsumed under class problems, and that a new kind of identity politics, influenced by debates over equality in the US and Europe, was emerging which required attention the State's attention. However, the process was, of course, cut short by the collapse of Soviet Communism and the economic crisis. Thus, not only did newly-emerging young writers find their manuscripts set aside (some later published these texts abroad), but the gender consciousness in writing that had begun to emerge in the 1980s was itself truncated by the broader context of severe austerity and survivalism of the early 1990s. Whilst women writers found that the demands of the doble or triple jornada had intensified in the absence of a state infrastructure (a public transport paralysis, power cuts, the scarcity of basic commodities), many writers also took the path of emigration or reemployment in the emerging tourist sector, allowing access to much-needed hard currency. But the women writers that remained - and the new writers that once again filled the 'void' as the publishing infrastructure slowly began to recover - found that their writing fulfilled a 
modified function in the new system. Their writing, inflected by feminist theories of self and writing, revealed an element of social and political commentary and critique but also focused predominantly on the personal implications of urgent social issues such as emigration, social inequality and fragmentation, disenchanted youth, racism, jineterismo, internationalism and generational change. Writers that had been producing a variety of texts since the 1960s, such as Yáñez and Marta Rojas, were now joined by successive generations, including Marilyn Bobes, Aida Bahr, and, importantly, by more recent cohorts of new writers, young and old, including Adelaida (Laidy) Fernández de Juan, Nancy Alonso and Susana Haug. At the same time, the need to publish abroad led to significant distortion of the national canon, with women suffering more acutely the effects of the national publishing crisis.

In Nicaragua, the first incursions by women into the literary landscape were, as in the Cuban case, often testimonial and generally hybrid, again underlining a notion of the function of the first waves of revolutionary literature being a way to represent history-in-the-making, and putting individual faces on the collective experience of insurrection and revolution. A key example is Margaret Randall's Todas estamos despiertas: testimonios de la mujer nicaragüense de hoy. However, one important distinction had already emerged long before the Sandinista government came to power: a tendency amongst those women writers who had participated in the clandestine urban movement and the insurrection (sometimes from exile) to draw a parallelism between sexual and political autonomy via an explicitly transgressive poetry that celebrated the specificities of the female body and its sexual and reproductive potential. The pre-1979 poetry of Belli, Vidaluz Meneses, Najlis, Rosario Murillo and Zamora thus represented an attempt to modify the relationship between the personal and the political, with Sandinismo and women's liberation acting as mutually constitutive elements designed to counteract the twin movements of patriarchy (to disembody or objectify women). These practices of 'writing the body', then, were clearly influenced by an emerging French feminist tradition grounded in psychoanalysis, and are perhaps most evident in Belli's prerevolutionary collections Sobre la grama and Linea de Fuego, and in Najlis's 1969 collection El viento armado.

In the period after the Sandinistas came to power, and in the context of cultural policy designed to massify and socialise literature, many of the women writers who had hitherto published in exile or had self-censored their writing continued to make strong links between 
political sovereignty and women's autonomy. However, what is less clear is to what extent their efforts to raise feminist awareness through literary production and reception were successful amongst the population at large. Although it is difficult to access much of the work published as part of the national Talleres de Poesía movement, it appears that there was little space accorded to the gynocentric and embodied style favoured by Belli et al, with greater attention given to a more conventional realist style (Jiménez 42). In this sense, it is also important to note that, unlike Cuba where the Catholic Church had quickly been excluded from ther power structures, Nicaragua's more inclusive political landscape attempted to bring together Marxists, liberation theologists and the Catholic Church, and writers of all kinds felt more able to draw on a more heterogeneous set of traditions of self and self-expression. This breadth of perspectives had both strengths and weaknesses: as Lorna Shaugnessy notes, 'It could be said that while Belli's poetry serves a feminist consciousness-raising function in its attempts to evoke sexual experience from a feminine perspective, she does not consider it necessary to adhere to the any ideological preconceptions of how, or what, that experience should be; like Sandinismo itself in the 1980s, her feminism displays many ideological inconsistencies' (Shaughnessy 178). Other writers, however, combining the 'double discursive strategy' of Marxism and Catholicism, were perhaps perceived as less literarily, but more politically, prestigious, often especially so when their writing fell into a more 'solid' realist tradition (Byron), often using the metonymic function indicated by Doris Sommers in relation to the now-infamous Rigoberta Menchú text (Sommers 146).

After the defeat of the FSLN in the 1990 elections, many Sandinista women writers broke abruptly with the traditions that had been developed since 1979: whilst some went into exile, published abroad and still remain disillusioned with the return of Daniel Ortega and the post2007 political system, others have attempted to continue the patterns established from 19791990, often using new technologies to disseminate texts that, in the absence of a robust national publishing infrastructure, would simply not be made public. Since 1990, these factors have taken some women's writing from Nicaragua down a more conservative path, with strong elements of retrospective self-justification and the tendency towards a coherent narrative and more interiorised subjectivity featuring in many of the generically hybrid texts that have appeared since 1990. 
One key figure who has continued the testimonial mode as established pre-1990 in Cuba and Nicaragua is the veteran FSLN Comandante Guerrillera Mónica Baltodano, who, with a four-volume collection, Memorias de la Lucha Sandinista, has brought together a large number of testimonies of the insurrection. Equally, texts in English (or in English translation) have attempted to establish some element of continuity of literary and political vision between the Sandinista period, the more recent past and the present: the re-publication of Randall's Sandino's Daughters in 1995 (originally published in Spanish) was prompted by the popularity of her 1994 volume Sandino's Daughters Revisited: Feminism in Nicaragua.

Violeta Barrios de Chamorro's memoirs of 1996, Dreams of the Heart, published a decade later in Spanish as Sueños del corazón, follows another paradigm of self-writing as an opportunity for the former president to establish her credibility as a statesman and woman in rather conservative terms, through blending the private and public. Belli's semiautobiographical novel La mujer habitada, her historical novel El pergamino de la seducción, and the poetry collection El ojo de la mujer have clearly taken her writing away from the referential specificities of revolutionary Nicaragua and into a more personal arena, which some scholars evaluate as a personal and political rupture with the past (Shaughnessy 184).

Equally, the void left by the discrediting of AMNLAE after 1990 was addressed in some measure by the creation in 2000 of a new organization, and virtual space, for Nicaraguan women writers, the Asociación Nicaraguense de Escritoras (ANIDE) which has some 70 members and promotes Nicaraguan women writers internationally (its national impact is less clear). In this sense, the testimonial mode (now via blogs, biographical information, interviews) remains relevant, although the impact of many of these writers in now evidently as international as it is national: since 1990, writers such as Zamora, Alegría, Najlis and Belli have divided their time, energies and manuscripts between Nicaragua and other countries, often publishing in translation or being re-published in anthologies in translation. As such, whilst in the case of Nicaragua, it is increasingly difficult to refer to a national canon of women writers - or at least that canon has been complicated by transnational opportunities and interests - the Cuban state has largely continued its commitment to a national publishing infracture post-crisis, and younger women writers have transformed the tradition established by the women writers of the 1960s and 1970s, adding a measure of interiority to the subjectivity and representation of women by women writers. 
In conclusion, then, the paradigmatic nature of many women-authored texts published under conditions of revolution can best be understood not only as a potentially transgressive entrance into nation-building projects, but also as an opportunity for women to crave out new identity positions within and against those projects. In this sense, and especially for subjects that were potentially transgressing the highly-gendered and class-based field of literature, women's writing continues to negotiate the delicate terrain of politics and gender.

\section{Works cited}

“Asociación Nicaragüense de Escritoras ANIDE.” n.d. Web. 1 July 2014.

Bayard de Volo, Lorraine. Mothers of Heroes and Martyrs. Gender Identity Politics in Nicaragua, 1979-1999. Baltimore, MD: John Hopkins University Press, 2001. Print.

Belli, Gioconda. Sobre la grama. Managua: n.p., 1978.

Belli, Gioconda. Línea de fuego. Havana: Casa de las Américas, 1978. Print.

Belli, Gioconda. La mujer habitada. Managua: Editorial Vanguardia, 1988. Print.

Belli, Gioconda. El pergamino de la seducción. Barcelona: Seix Barral, 2006. Print.

Belli, Gioconda. El ojo de la mujer. Poesía reunida. Madrid: Visor Libros, 2002. Print.

Beverley, John, and Marc Zimmerman. Literature and Politics in the Central American Revolutions. Austin: University of Texas Press, 1990. Print.

Borge, Tomás. Women and the Nicaraguan Revolution. London: Pathfinder Press, 1982. Print.

Byron, Kristine. "Doris Tijerino. Revolution, Writing and Resistance in Nicaragua." National Women's Studies Association Journal 18/3 (Fall 2006): 104-121. Print.

Campuzano, Luisa. "Cuba 1961: los textos de las alfabetizadoras. Conflictos de género, clase y cánon.” Unión 26 (enero-marzo 1997): 52-58. Print.

Campuzano, Luisa. Quirón o del ensayo y otros eventos. Havana: Editorial Letras Cubanas, 1988. Print.

Castro Ruz, Fidel. "Palabras a los intelectuales.” Discurso pronunciado por el Comandante Fidel Castro Ruz, Primer Ministro del Gobierno Revolucionario y Secretario del PURSC, como conclusión de las reuniones con los intelectuales cubanos, efectuadas en la Biblioteca Nacional el 16, 23 y 30 de junio de 1961. Web. 10 August 2014.

Castillo Bueno, Maria de la Reyes. Reyita. The Life of a Black Woman in the Twentieth Century. Trans. Ann McLean. Durham: Duke University Press, 2000. Print. 
Chamorro, Violeta Barrios de. Dreams of the Heart. New York: Simon and Schuster, 1996. Print.

Chamorro, Violeta Barrios de, et al. Sueños del corazón. Memorias. Trans. Andrés Linares. Managua: Fundación Violeta Barrios de Chamorro, 2007. Print.

Dore, Elizabeth, and John Weeks. The Red and the Black. The Sandinistas and the Nicaraguan Revolution. London: University of London (Institute of Latin American Studies Working Papers 28, 1992. Print.

Davies, Catherine. A Place in the Sun? Women Writers in Twentieth-Century Cuba. London: Zed Books, 1997. Print.

Dawes, Greg. Aesthetics and Revolution. Nicaraguan Poetry, 1979-1990. Minnesota: University of Minnesota Press, 1990. Print.

Fagen, R. R. The Transformation of Political Culture in Cuba. Stanford: Stanford University Press (Stanford Studies in Comparative Politics, 2), 1969. Print.

Jiménez, Mayra, ed. Poesía de la Nueva Nicaragua: Talleres Populares de Poesía. Mexico D.F.: Siglo Veintiuno Editores, 1983. Print.

Kapcia, Antoni. Cuba: Island of Dreams. Oxford: Berg, 2000. Print.

Kumaraswami, Par. "Pensamos que somos historia porque sabemos que somos historia'. Context, Self and Self-construction in Women's Testimonial Writing from Revolutionary Cuba." Bulletin of Hispanic Studies 83/6 (2006): 523-39.

Kumaraswami, Par, and Antoni Kapcia. Literary Culture in Cuba. Revolution, Nationbuilding and the Book. Manchester: Manchester University Press, 2012. Print.

Medin, Tzvi Cuba: The Shaping of a Revolutionary Consciousness. Boulder: Lynne Rienner Publishers, 1990. Print.

Memorias de la Lucha Sandinista. Ed. Mónica Baltodano. Web. 3 August 2014.

Molyneux, Maxine. "Mobilization without Emancipation? Women's Interests, the State, and Revolution in Nicaragua." Feminist Studies 11/2 (Summer 1985): 227-254. Print.

Morejón, Nancy, and Carmen Gonce. Lengua de pájaro. Comentarios reales. Havana: Insitituto del Libro, 1967. Print.

Najlis, Michelle. El viento armado. Guatemala: Editorial Universitaria, 1969. Print.

Olema Garcia, Daura. Maestra voluntaria. Havana: Casa de las Américas, 1962. Print. Randall, Margaret. Todas estamos despiertas: testimonios de la mujer nicaragüense de hoy. Historias inmediatas. Mexico D.F.: Siglo Veintiuno Editores, 1980. Print.

Randall, Margaret. Sandino's Daughters. Testimonies of Nicaraguan Women in Struggle. 1981. New Brunswick: Rutgers University Press, 1995. Print. 
Randall, Margaret. Sandino's Daughters Revisited. Feminism in Nicaragua. New Brunswick: Rutgers University Press, 1994. Print.

Santos Moray, Mercedes. La piedra de cobre. Havana: Editorial Letras Cubanas, 1981. Print.

Serra, Ana. The "New Man" in Cuba. Culture and Identity in the Revolution. Gainesville: University Press of Florida, 2007. Print.

Shaughnessy, Lorna. "Problemas de la transición. Sexual emancipation and social transformation in the poetry of Gioconda Belli (1970-1992)." Revolucionarias: Conflict and Gender in Latin American Narratives by Women. Ed. Par Kumaraswami and Niamh Thornton . Oxford: Peter Lang 2007. 165-190. Print.

Smith, Lois M., and Alfred Padula. Sex and Revolution. Women in Socialist Cuba. Oxford: Oxford University Press, 1996. Print.

Smith, Verity. "What are Little Girls made of under Socialism? Cuba's Mujeres and Muchacha in the Period 1980-1991." Studies in Latin American Popular Culture 4 (1995): 115. Print.

Sommer, Doris. 'No Secrets'. The Real Thing. Testimonial Discourse and Latin America. Ed. Georg Gugelberger. Durham: Duke University Press, 1996. 130-157. Print.

Steedman, Carolyn. Past Tenses: Essays on Writing, Autobiography and History. London: Rivers Oram Press, 1992. Print.

Yáñez, Mirta. Todos los negros tomamos café. Havana: Editorial Arte y Literatura, 1976. Print. 